\title{
Retropharyngeal hematoma: Two case reports
}

\author{
Retrofarengeal hematom: İki olgu sunumu
}

Abdurrahman Buğra Cengiz $(\mathbb{D}$, Hasan Deniz Tansuker $(\mathbb{D}$

Department of Otolaryngology, University of Health Sciences, Bağcllar Training and Research Hospital, Istanbul, Türkiye

\begin{abstract}
Retropharyngeal hematoma $(\mathrm{RH})$ is a rare but potentially serious complication of whiplash head trauma and anticoagulantinduced coagulopathy (AIC). The literature is undecided on the management of the hematoma by surgical drainage, and the data in the literature is abundant. We report two patients presented to emergency service with different etiologies and symptoms. The first case is the spontaneous $\mathrm{RH}$ of a patient who could not adjust the dosage of warfarin sodium they had been using long-term due to heart valve disease, and the second case is an isolated hematoma after minor head trauma in a child. While the first patient required an urgent tracheotomy, we applied conservative treatment in the second patient. The treatment of RH may differ according to etiology and severity of symptoms. Once symptoms of airway blockage arise, the airway must be immediately secured before complete obstruction occurs. The diagnosis of RH should be considered when an anticoagulated patient presents with upper airway symptoms.
\end{abstract}

Keywords: Anticoagulation, pediatric trauma, retropharyngeal hematoma, tracheotomy, whiplash.

The retropharyngeal space is a potential space of the head and neck, bordered by the buccopharyngeal fascia anteriorly and the alar fascia posteriorly which contains lymph nodes and vessels. Retropharyngeal hematomas $(\mathrm{RHs})$ are rare and potentially life-threatening entities due to their proximity to the upper airway. Causes of RHs include infection, cervical spine or vessel trauma, violent head movements, whiplash injuries, iatrogenic injury as a complication of central line and nasogastric tube placement and foreign-body
$\ddot{O} Z$

Retrofarengeal hematom ( $\mathrm{RH})$, whiplash kafa travması ve antikoagülan kaynaklı koagülopatinin (AKK) nadir fakat potansiyel olarak ciddi bir komplikasyonudur. Literatürde, hematomun cerrahi drenajı kararı konusunda ikilem vardır ve fazla veri bulunmaktadır. Bu yazıda, acil servise farklı etyoloji ve semptomlarla başvuran iki ayrı olgu sunuldu. İlk olgu, kalp kapak hastalığı nedeniyle uzun süredir varfarin sodyum kullanan ve ilacın dozunu ayarlayamayan bir hastada gelişen spontan RH idi ve ikinci olgu, bir çocukta minör kafa travmasından sonra izole bir hematom idi. İlk hastaya acil trakeotomi gerekirken ikinci hastaya konservatif tedavi uygulandı. Retrofarengeal hematomda tedavi, etyolojiye ve semptomların şiddetine göre değişebilir. Hava yolu tıkanıklığı belirtileri ortaya çıktığında, tamamen tıkanma meydana gelmeden önce hava yolu derhal emniyete alınmalıdır. Antikoagüle bir hasta üst solunum yolu semptomları gösterdiğinde RH tanısı düşünülmelidir.

Anabtar sözcükler: Antikoagülasyon, pediyatrik travma, retrofarengeal hematom, trakeotomi, whiplash.

ingestion. ${ }^{[1]}$ In addition, it may occur as a spontaneous unprovoked bleeding event. Patients with hemophilia and those taking anticoagulants such as coumadin has an increased risk of $\mathrm{RH} \cdot{ }^{[2]}$

We report two cases of $\mathrm{RH}$ presented with different causes. One of the cases was an elderly female under warfarin anticoagulation for heart valve disease with no history of trauma, and the second case was a child with an isolated hematoma after minor head

Received: May 14, 2020 Accepted: March 03, 2021 Published online: August 13, 2021

Correspondence: Abdurrahman Buğra Cengiz, MD. SBÜ Bağcılar Eğitim ve Araştırma Hastanesi, Kulak Burun Boğaz Kliniğì, 34200 Bağcllar, İstanbul, Türkiye. e-mail: drcengiz@gmail.com 
trauma. While the first patient required an urgent tracheotomy, conservative treatment was applied to the second patient. The treatment may differ according to etiology and severity of symptoms. We aimed to review the pertinent literature and discuss the diagnosis and treatment of this entity.

\section{CASE REPORT}

Case 1- A 78-year-old female presented to the emergency department (ED) complaining of dyspnea, sore throat and difficulty swallowing. The patient had a history of coronary artery disease, hypertension and aortic valve replacement, and the patient had been taking $75 \mathrm{mg}$ of clopidogrel and $5 \mathrm{mg}$ of coumadin daily in addition to a $100 \mathrm{mg}$ aspirin tablet and antihypertensive drugs. The patient had no history of surgery, trauma or violent head movement. Upon physical examination, the patient presented with a pulse rate of 113 beats $/ \mathrm{min}$, a respiratory rate of $30 / \mathrm{min}$, an oral temperature of $37^{\circ} \mathrm{C}$ and blood pressure of $150 / 80 \mathrm{mmHg}$. Oxygen saturation was $86 \%$. Physical examination of the head and neck revealed a local swelling over the right side of the neck. The patient spoke in a muffled voice with stridor. Indirect laryngoscopy revealed a large right-sided soft, bulging, violaceous mass involving the posterior and lateral pharyngeal walls in the right side of the epiglottis on the right aryepiglottic folds, and postcricoid area vocal cords could not be evaluated. Pain was elicited on flexion or extension of the neck.

Laboratory studies were significant for an International Normalized Ratio (INR) of 8.2 (therapeutic range: 2-3), a prothrombin time (PT) of
$57.4 \mathrm{sec}$ with a partial thromboplastin time (PTT) of $220 \mathrm{sec}$ (normal range: 22-34 sec). The results of the other laboratory tests were normal. Neck computed tomography (CT) with contrast showed a $34 \times 55 \mathrm{~mm}$ sized heterogeneous hyperdense thickness in the retropharyngeal space (Figure 1). The hematoma was extending from the skull base to the thoracic inlet, which obstructed the airway in the oropharynx and caused the lateral displacement of both carotid arteries. The mass heterogeneity was ranging from 50 to $70 \mathrm{HU}$, and dilated and tortuous vessels were present within the lesion, compatible with hematoma (Figure 2). The patient could not tolerate magnetic resonance imaging (MRI) due to stridor. Coumadin was stopped, and the patient was transfused with four units of fresh frozen plasma and injected with subcutaneous vitamin $\mathrm{K}$ (10 mg). Subsequently, the patient underwent an urgent tracheotomy due to increased acute distress and stridor. Direct laryngoscopy revealed edematous changes with a hematoma over the oropharynx, larynx and the beginning of the esophagus. The airway was pushed upwards, and the vocal cords were intact. There was no active bleeding. We did not perform surgical drainage, just waited for spontaneous resolution. After surgery, the patient stayed in the intensive care unit for two days then was transferred to the clinic. INR level decreased to 2.5. The airway examination remained stable, swallowing improved, and the pain regressed. After five days, retropharyngeal swelling decreased by half on the exam, and the tracheostomy was closed. The patient was discharged home after nine days in the hospital with complete resolution of symptoms. A written informed consent was obtained from the patient.
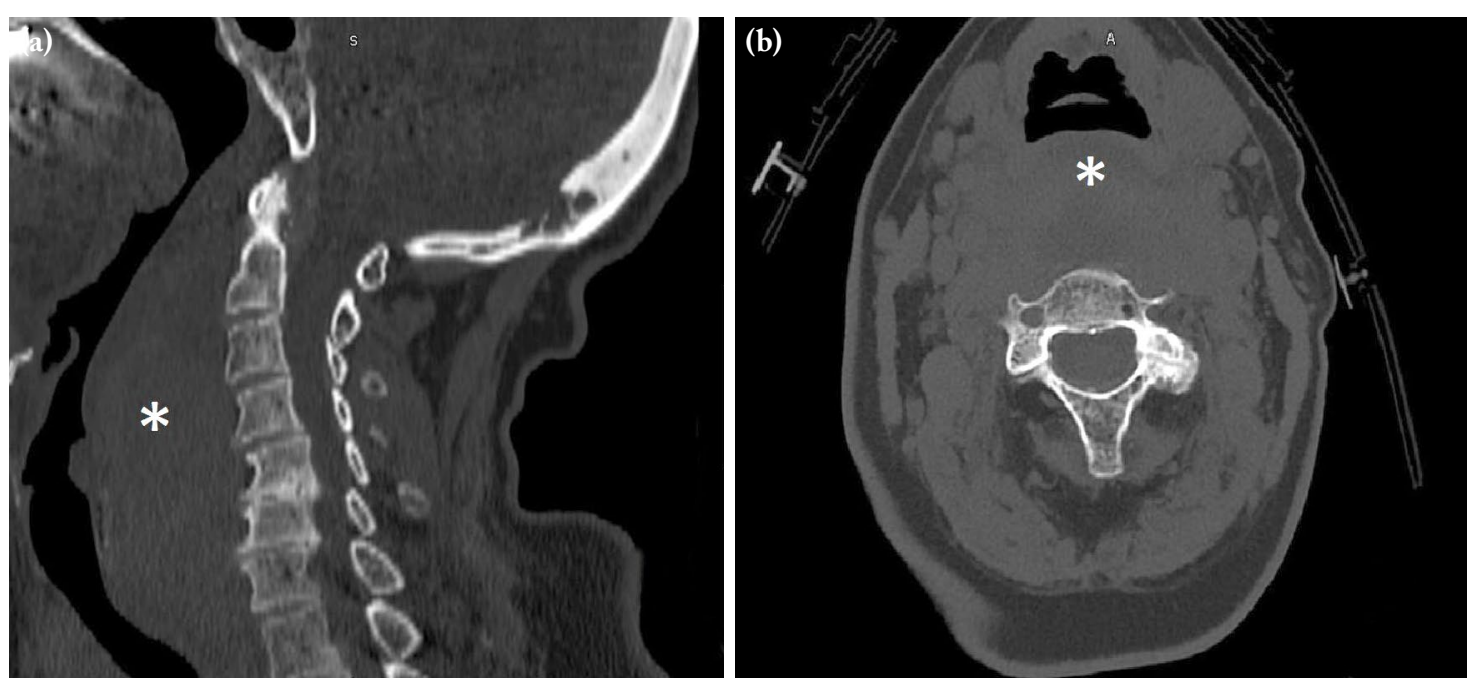

Figure 1. (a) Sagittal and (b) axial plane computed tomography of the neck showing a retropharyngeal mass spreading to the whole retropharyngeal space and compressing the upper airway (asterisks). There are contrast extravasation lesions due to active bleeding. 


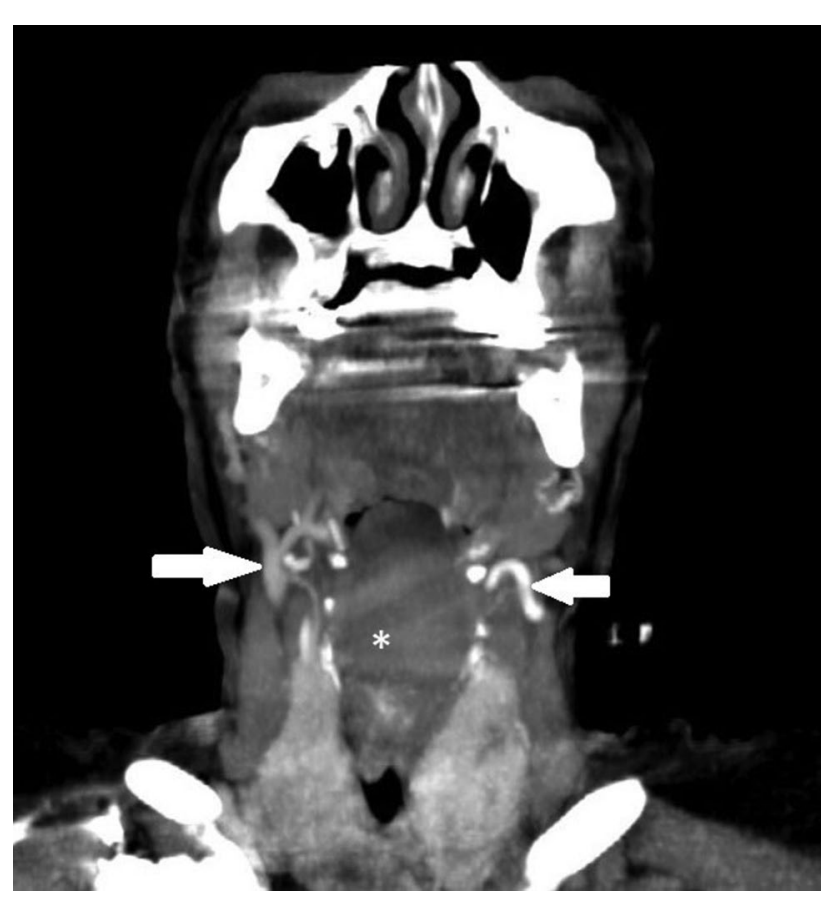

Figure 2. Coronal plane tomography of the neck and chest, demonstrating a huge hematoma that is extending from the skull base to the thoracic inlet (asterisks) and laterally displacing both carotid arteries (white arrows).

Case 2- A four-year-old female presented to the ED with pain and stiffness in her neck for the last three days with a history of hitting their neck against the stair and obtuse trauma. Movement of the neck was painful and restricted. Additionally, tenderness was observed in the cervical spine after palpation. Initially, the patient was consulted to the neurosurgery department, and no neurological deficit was found. The patient's Quebec grade was two. ${ }^{[3]}$ Plain radiograms showed normal lordotic curvature of the cervical spine. Craniocervical $\mathrm{CT}$ from the vertex to the $\mathrm{C} 7$ vertebra demonstrated no signs of fracture or intracranial pathology. Cervical MRI showed a heterogeneous hypodense lesion on T1-weighted and hyperdense lesion in T2-weighted images in the sagittal and axial planes obliterating nasopharyngeal airway consistent with RH (Figure 2). Prevertebral spaces were widened $6 \mathrm{~cm}$ from nasopharynx to oropharynx. The patient was administered antibiotic and anti-inflammatory therapy and immobilized by a cervical collar, with no further intervention. No additional deficit was seen during follow-up period.

The symptoms of the patient almost completely resolved on the fourth day. A second MRI showed an organizing hematoma confined to the left longus capitis muscle, obliterating the left retropharyngeal space and causing airway obstruction at the same level on the first week after trauma. However, a comparison of the new images with the previous ones demonstrated gradual improvement in both the size of the hematoma and the size of the obliteration (Figure 2). The patient was discharged after 10 days. The one-month followup revealed no pain or movement problems. A written informed consent was obtained from the official guardian of the patient.
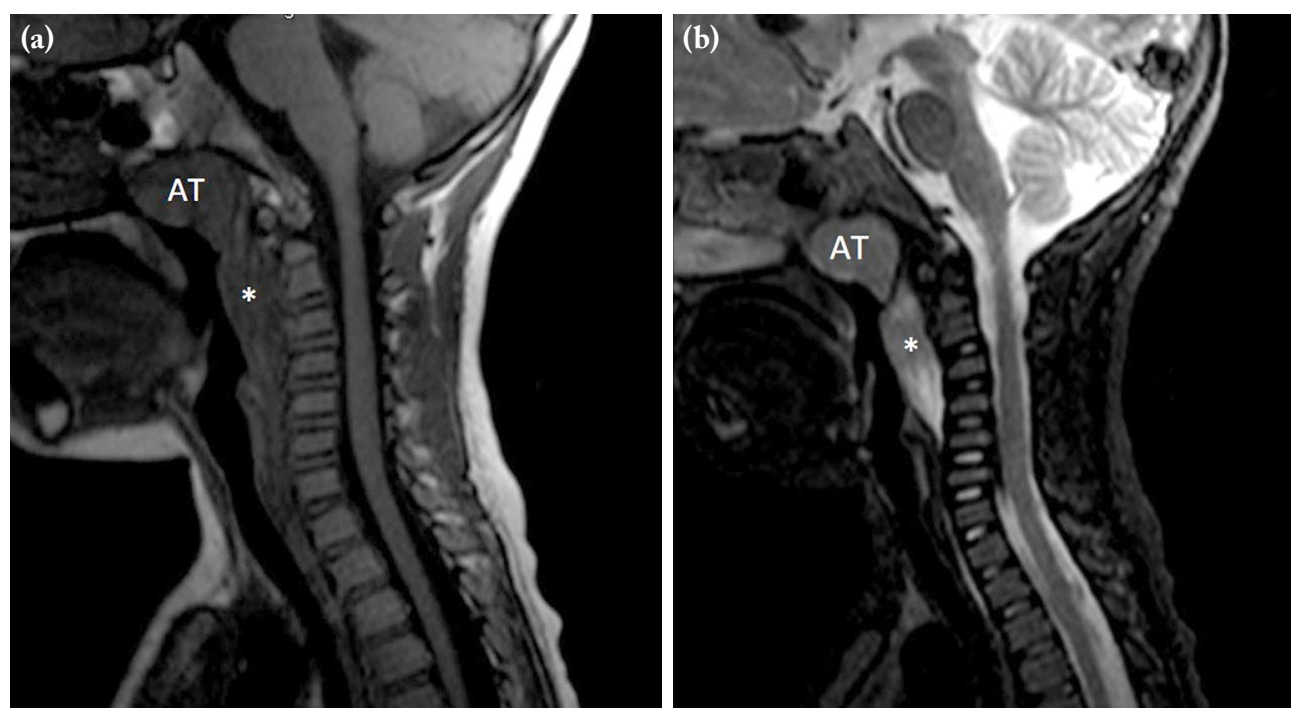

Figure 3. (a) $\mathrm{T} 1$ and (b) $\mathrm{T} 2$ weighted sagittal magnetic resonance images demonstrating retropharyngeal swelling and hematoma in the second patient. (asterisks) Note that the adenoid tissue has a similar density compared to the retropharyngeal hematoma. AT: Adenoid tissue. 


\section{DISCUSSION}

The retropharyngeal space is located between the vertebral column and pharynx and is more important than the other spaces in the neck since its located dorsal to the airway, and its obstruction due to $\mathrm{RH}$ can be life-threatening. There are two main reasons of RH: trauma and bleeding diathesis. ${ }^{[4]}$ While a history of trauma is the most frequent reason, spontaneous $\mathrm{RHs}$ may also occur, typically in those with bleeding diathesis due to genetic disorders or oral anticoagulants. ${ }^{[5]}$

Less than seventy cases have been reported in the literature on airway obstruction due to $\mathrm{RH}$ with isolated trauma and no spine injury. ${ }^{[6]}$ Etiologies range from blunt trauma to whiplash injury and foreign body ingestion. ${ }^{[7]}$ Whiplash injury is known as a cervical soft tissue hyperextension-flexion injury after a trauma such as rear-end impact car crash, sports injuries, blow to the head from a falling object or a punch, and shaken baby syndrome, and has generally been reported as an adult phenomenon. Symptoms include head, neck, shoulder, back and/or temporomandibular joint pain and back and neck muscle spasms. Hematoma formation may extend from the base of the skull to the tracheal bifurcation. Dysphagia, dysphonia, dyspnea and stridor can be added to symptoms according to the severity of bleeding. ${ }^{[8]}$ Retropharyngeal hematoma without additional pathology, as seen in the second case, is very rare. Boyd et al. ${ }^{[9]}$ reported a large clinically evaluated group of children with whiplash trauma. Their study revealed that almost half of the children presented to the emergency room had head and neck pain. Nevertheless, none of the cervical spine radiographs were reported as RH. Nurata et al. ${ }^{[10]}$ reported a fouryear-old male admitted to the emergency room with restricted neck movement and pain. The symptoms had improved by the application of the cervical collar, analgesic and anti-inflammatory therapy by the end of the first week. Similarly, neither respiratory distress nor any vital disturbance was present in our first patient and our patient was discharged after 10 days of follow-up.

Coumadin shows effect by blocking the vitamin $\mathrm{K}$-dependent reducing enzymes that provide the carboxylase substrate, which is necessary for the activation of coagulation factors II, VII, IX and X. Coumadin's half-life is $35 \mathrm{~h}$ with anticoagulant effects lasting for three to five days. Blood level of coumadin is globally measured by the INR. Usage of anticoagulant and antiplatelet drugs has been clearly associated with an overall higher risk of instant bleeding attacks and death from intracranial or intraabdominal hemorrhages. ${ }^{[1]]}$ In addition to the overdose of anticoagulant drugs, diet, medical conditions and other medications may also affect the level of anticoagulation. Reported upper airway locations of oral anticoagulant-induced hematomas include the submandibular and sublingual space, the peritonsillar area, the parapharyngeal and retropharyngeal spaces and the glottic area ${ }^{[12-14]}$ According to a review, $\mathrm{RH}$ was the second most common cause of upper airway obstruction due to AIC and there were only 38 anticoagulant-induced $\mathrm{RH}$ cases in the literature. ${ }^{[15]}$ Various approaches to manage $\mathrm{RH}$ have been successfully implemented. Initially, the airway safety must be assured. Then, the adjustment of coagulopathy in those taking anticoagulants should be made. Tessler et al. ${ }^{[16]}$ recommended early tracheotomy in all patients, with observation limited to only mild cases. Similarly, some authors support conservative management with close monitoring for three weeks until a complete resolution of underlying hematoma occurs if the patient has mild symptoms. ${ }^{[17]}$ Our second patient with airway obstruction symptoms and high INR levels underwent tracheotomy on the day of admission to the ED. After a close follow-up in the intensive care unit, the $\mathrm{RH}$ resorbed and the patient was discharged home with complete resolution of symptoms.

In conclusion, $\mathrm{RH}$ is a rare but potentially fatal complication of anticoagulant therapy, which should be differentiated from the more common infectious etiologies. It is more common in the elderly population and presents with a high INR level in most cases. The other main etiology is head trauma, particularly caused by a cervical soft tissue hyperextension-flexion injury. It is important as it may cause severe airway obstruction and mortality due to bleeding amongst deep cervical fascias. The treatment may vary from follow-up to tracheotomy according to severity of symptoms.

\section{Declaration of conflicting interests}

The authors declared no conflicts of interest with respect to the authorship and/or publication of this article.

\section{Funding}

The authors received no financial support for the research and/or authorship of this article.

\section{REFERENCES}

1. Pamukçu Günaydın G, Çiftçi Sivri HD, Sivri S, Otal Y, Özhasenekler A, Kurtoğlu Çelik G. Concurrent spontaneous sublingual and intramural small bowel hematoma due to warfarin use. Case Rep Emerg Med 2015;2015:583869.

2. Lin JY, Wang CH, Huang TW. Traumatic retropharyngeal hematoma: Case report. Auris Nasus Larynx 2007;34:423-5.

3. Seferiadis A, Rosenfeld M, Gunnarsson R. A review of treatment interventions in whiplash-associated disorders. Eur Spine J 2004;13:387-97. 
4. Betten DP, Jaquint JL. Traumatic retropharyngeal hematoma in a patient taking clopidogrel. Case Rep Emerg Med 2018;2018:6147473.

5. Udy A, Senthuran S, Lipman J. Airway obstruction due to a pre-vertebral haematoma following difficult central line insertion--implications for ultrasound guidance and review of the literature. Anaesth Intensive Care 2009;37:309-13.

6. Baek JH, Kim JH. Retropharyngeal hematoma secondary to cervical hyperextension in a minor collision trauma presenting with dyspnoea: A case report. Medicine (Baltimore) 2020;99:e21528.

7. Mitchell RO, Heniford BT. Traumatic retropharyngeal hematoma--a cause of acute airway obstruction. J Emerg Med 1995;13:165-7.

8. Senel AC, Gunduz AK. Retropharyngeal hematoma secondary to minor blunt neck trauma: Case report. Rev Bras Anestesiol 2012;62:731-5.

9. Boyd R, Massey R, Duane L, Yates DW. Whiplash associated disorder in children attending the emergency department. Emerg Med J 2002;19:311-3.

10. Nurata H, Yilmaz MB, Borcek AO, Oner AY, Baykaner MK. Retropharyngeal hematoma secondary to whiplash injury in childhood: A case report. Turk Neurosurg 2012;22:521-3.
11. Lavoie A, Ratte S, Clas D, Demers J, Moore L, Martin $\mathrm{M}$, et al. Preinjury warfarin use among elderly patients with closed head injuries in a trauma center. J Trauma 2004;56:802-7.

12. Jandreau SW, Mayer D. Spontaneous bilateral arytenoid hematoma in a patient on warfarin. Am J Emerg Med 1998;16:674-6.

13. Galván CA, Guarderas JC. Practical considerations for dysphonia caused by inhaled corticosteroids. Mayo Clin Proc 2012;87:901-4.

14. Magos T, Barnes M. Beware of upper airway obstruction in warfarinized patients. J Anaesthesiol Clin Pharmacol 2018;34:550-2.

15. Karmacharya P, Pathak R, Ghimire S, Shrestha P, Ghimire $\mathrm{S}$, Poudel DR, et al. Upper airway hematoma secondary to warfarin therapy: A systematic review of reported cases. N Am J Med Sci 2015;7:494-502.

16. Tessler I, Adi M, Diment J, Lahav Y, Halperin D, Cohen O. Spontaneous neck hematoma secondary to parathyroid adenoma: A case series. Eur Arch Otorhinolaryngol 2020;277:2551-8.

17. Docimo S Jr, Demin A, Vinces F. Patients with blunt head trauma on anticoagulation and antiplatelet medications: Can they be safely discharged after a normal initial cranial computed tomography scan? Am Surg 2014;80:610-3. 